\title{
Substitute Public Notary Accountability Process The Negligent In Agreement (Case Study In Semarang)
}

\begin{abstract}
Angga Wisnu Firmansyah ${ }^{1}$ and Maryanto ${ }^{2}$
Abstract. Notary is within the meaning of the Act No. 30 of 2004 concerning Notary in Article 1 is mentioned sense Public notary officials who are authorized to make an authentic agreement and other authorities referred to in this Act. But not forever Notaries can continue to work, in this case, a notary can appoint a replacement to run the temporary Notary and his task. Substitute Notary has the same authority to the notary replaces. With their equality between the legal position with the Substitute Public Notary, then there are no doubts anymore that the agreement made by Notary Substitutes have the same legal force by agreement of Notary. This study is a socio-juridical, then studied at first is by using secondary data library materials and then proceed with research on primary data obtained from the field by taking into account the applicable legal norms connected with the facts found from the study.

Keywords: Authority; Notary; the Notary Substitute Responsibility.
\end{abstract}

\section{Introduction}

The Republic of Indonesia is a Constitutional State based $^{3}$ on Pancasila and the Constitution of the Republic of Indonesia of 1945 and law has the highest position in the Government, and the Law is the protection of human interests. State of Law is a state based on law and justice for its citizens ${ }^{4}$. The point is all of the authority and actions of the State scientific equipment or otherwise regulated by law. Such a situation would reflect social justice for its citizens living. The law governs all law relations between individuals, individuals with society and the individual with the Government ${ }^{5}$.

In the Constitution of the Republic of Indonesia in 1945 (then called UUD 1945) expressly stated that the Republic of Indonesia is State of Law, and is therefore one of the most important tasks for the Government is provide and guarantee their Sense Legal Certainty for citizens. The member of which is the presence of Notary, the Notary Understanding is the understanding According to Act No. 30 of 2004 was amended by Act No. 2 of 2014 Notary in Article 1 is mentioned sense Public notary Officials authorized to make the Authentic Agreements and other authorities referred to in this Law of Notary. It born because people need it, not position were deliberately created and then a new socialization to the people.

Notary is not placed in the judicial institution, the executive or the Legislature for Notary expected to have a neutral position. Notary held or presence is desired by the Rule of Law with a view to help and serve the people who need equipment that is Authentic Written evidence about the circumstances, events or acts of Law.

1 Student of Master Program (S2) of Notaries Faculty of Law UNISSULA Semarang email anggawisnuf19@yahoo.co.id

2 Lecturer of Faculty of Law UNISSULA

${ }^{3}$ Sudikno Mertokusumo 2003 Mengenal Hukum Suatu Pengantar Liberty Yogyakarta p.21.

${ }^{4}$ Abdul Aziz Hakim 2011 Negara Hukum dan Demokrasi Yogyakarta Pustaka Pelajar p.8

5 Mochtar Kusumaatmadja 2000 Pengantar Ilmu Hukum Suatu Pengenalan Pertama Ruang Lingkup Berlakunya IImu Hukum Alumni Bandung p. 43 
Book of the Civil Law (Civil Code) in accordance with the provisions of Article 1868 authentic clarified that an agreement is an agreement that is shaped and defined by the Act, made by or before officials of the ruling General to determine where the Acts are made. The goal made written agreements before or Notary is that it becomes authentic agreement that can be used as evidence if one day there is a dispute between the parties or there is a lawsuit from the other party. Authentic Agreement can be said to have the strength of evidence was perfect because it has three strength of evidence, namely the strength of evidence outward, formal proof strength, and the strength of evidence material ${ }^{6}$

Therefore, a Notary in his duties shall carry out their duties with discipline, professional and moral integrity should not be in doubt. What is stated in the beginning and end of the agreement is the responsibility of the notary is a phrase that reflects circumstances, True at the time of manufacture of the Agreement. ${ }^{7}$

One of the obligations of the notary is read agreement before client in the presence of at least two (2) witnesses or four (4) witnesses, specifically for the manufacture of the Agreement of wills under the hands and signed on the spot by client, witnesses and Notary, set in Article 16 paragraph (1) letter L UUJN.

So, naturally when the Notary as Public Official who is appointed by the State and working for the State Law afforded protection to taste ${ }^{8}$. Since the scope of work is very broad and complex, have a duty and responsibility is very heavy, to realize the intent and purpose of the parties who want Authentic agreement as Evidence is good, true and not deformed Law.

But not forever Notaries can continue to work, because the Notary also human beings who can be hindered in carrying out His post, for that in carrying out its obligations as a human being Notary also entitled to while not doing its job (on leave) as General Authorities. Notary leave may be granted if a Notary has conducted his post for two years and if it is less than 2 years, the Notary can not take the leave rights.

In this case, a notary can appoint a replacement to run the temporary Notary and position. Notary Substitute task has the same authority to the Notary replaces. With the same notch Law of Notary Substitute to Notaries, then there are no doubts anymore that the Agreement of Notary Substitute has the power law similar to the Agreement of Notary, which means that the Acts made by or before a Notary Substitute is Authentic and have the perfect strength of evidence referred to in article 1870 BW. In making the Notary Substitute must include the date and number designation and officials who appointed and include the name of notaries who temporarily replaced.

\section{Research Methods}

This study using sociological juridical approach, then studied at first is by using secondary data library materials and then proceed with research on primary data obtained from the field with the observance of law in force associated with the facts found from the study. The data used are primary data and secondary data processing and analysis of materials

6 https://bh4kt1.wordpress.com/2010/12/30/otentisitas-suatu-Akta-Autentik/ accessed on August 52018 at 19:16 pm

7Tan Thong Kie 2000 Studi Notariat-Serba Serbi Praktek Notaris Jakarta Ichtiar Baru VanHoeve p. 166.

8 Paulus Effendie Lotulong 2002 Perlindungan Hukum Bagi Notaris Selaku Pejabat Umum Dalam Menjalankan Tugasnya Media Notariat edisi April-Juni 2002 Ikatan Notaris Indonesia p.1. 
and engineering techniques as for the legal description or circumstances exposing phenomena in description techniques are not looking for or explain the relationship, do not test hypotheses or make predictions. ${ }^{9}$ Description of what it means to a condition or position of the propositions of law or non-law. This thesis described is the Notary Substitute Accountability Process The Negligent In Agreement.

\section{Results And Discussion}

\subsection{Substitute Public notary Accountability Forms When In Making Agreement}

Act No. 30 of 2004 concerning Notary (UUJN) does not regulate criminal provisions. UUJN only sanctions for violations committed by the Notary to UUJN, these penalties may include sanctions against the agreement had made and of the Notary. Sanctions against the agreement that made make Agreement Notary Agreement slumming of Authentic or be agreement under the hand, while for the Notary be given sanctions ranging from a reprimand to lead to a dishonorable discharge.

Criminal acts are prohibited by a rule of law, if the violation of the ban will diiukuti by certain criminal sanctions in the form. In carrying out his position as a Public notary, Criminal Code is meant is performed by a Notary in his capacity as General Authorities authorized to make the Authentic Agreements diamanakhan by UUJN, not an individual personal capacity or as a subject of the Notary Law. Responsibility held by the Notary / Notary Substitute the principle of liability based on fault (based on fault of liability), in the manufacture of Authentic agreement, a notary must be responsible if the above agreement he made there are any errors or deliberate infringement by the Notary /Substitute Notary still have to be responsible for the product good agreement when he was serving as Substitute notary or after the ending of duty office. Notary not participate sustain all the problems of the Notary Agreement in Lieu of which will arise in the future, although the Protocol notary has returned to the notary replaces, for the manufacture of it. Notary Agreement does not intervene in the making of a Substitute Notary. Because officer independently, is solely responsible for agreement. And Notary / Notary substitute would get a civil sanction the Notary / Notary Substitute prepared to deal with the injured party lawsuit, which the lawsuit as an act against the law.

\subsection{The Role of the Honorary Council forms of Notary Region All Make Mistakes In Making Agreement.}

Notary Honorary Council established pursuant to the mandate of Act No. 2 of 2014 and Ministry Regulation and Human Rights No. 7 of 2017 Article 20. The establishment of this body aimed at protecting the good name of the Notary of the investigator, the prosecutor general, and the judge's decision and calling "minuta" of Notary Agreement and in order to provide guidance and oversight to the Notary in running the office profession as General Authorities, constantly improve the professionalism and quality of work, so as to guarantee certainty and protection of the Law for the recipients of the Notary, because of the Notary is not for the benefit of the Notary itself but for the benefit of society served or enlist the services of a Notary. Honorary Council of Notaries Region has the authority to conduct an examination of the application submitted by the investigator, the prosecutor general, and judge; and give approval or rejection of the request for approval to attend the Notary calling the investigation, prosecution and the judicial process.

\footnotetext{
9 M. Hariwijaya 2007 Metodologi Dan Teknik Penulisan Skripsi Tesis Dan Disertasi Azzagrafika Yogyakarta p. 48
} 
Throughout what has been done by the Notary is in conformity with the provisions of legislation, especially Law of Notary (UUJN) and does not violate the code of conduct that has been determined, it does not permit the Honorary Council of Notaries Notary concerned to meet the law enforcement authorities, although only as a witness.

\section{Closing}

\subsection{Conclusion}

- In making the Authentic Agreements, a notary must be responsible if the above agreement he made there are any errors or deliberate infringement by the Notary /Substitute Notary still have to be responsible for the product good agreement when he was serving as Substitute notary or after the ending of duty office. Notary not participate sustain all the problems of the Notary Agreement in Lieu of which will arise in the future, although the Protocol notary has returned to the notary replaces, for the manufacture of it. Notary Agreement does not intervene in the making of a Substitute Notary. Because officer independently, is solely responsible for agreement.

- Honorary Notary Region has the authority to conduct an examination of the application submitted by the investigator, the prosecutor general, and judge; and give approval or rejection of the request for approval to attend the Notary calling investigation, prosecution, and the court process. As long as what has been done by the Notary is in conformity with the provisions of legislation, especially Law Notary (UUJN) and does not violate the code of conduct that has been determined, the Honorary Council does not allow Notary concerned to meet the law enforcement authorities, although only as a witness.

\subsection{Suggestion}

Supposedly form of accountability between the Notary and Notary Substitute should be differentiated, because it is only temporary Substitute Notary or just help replace the Public Notary during free work. Similar in terms of accountability will certainly make Notary Substitute feel heavy, considering sanctions and the burden given to him very hard because if there is a fault will be sanctioned civil or criminal.

\section{References}

[1] Sudikno Mertokusumo 2003 Mengenal Hukum Suatu Pengantar Liberty Yogyakarta.

[2] Abdul Aziz Hakim 2011 Negara Hukum dan Demokrasi Yogyakarta : Pustaka Pelajar

[3] Mochtar Kusumaatmadja Pengantar IImu Hukum Suatu Pengenalan Pertama Ruang Lingkup Berlakunya IImu Hukum Alumni Bandung 2000.

[4] https://bh4kt1.wordpress.com/2010/12/30/otentisitas-suatu-Akta-Autentik/ accessed on 5 August 2018 at 19:16 WIB

[5] Tan Thong Kie 2000 Studi Notariat-Serba Serbi Praktek Notaris Jakarta:Ichtiar Baru VanHoeve

[6] Paulus Effendie Lotulong 2002 Perlindungan Hukum Bagi Notaris Selaku Pejabat Umum Dalam Menjalankan Tugasnya Media Notariat edisi April-Juni 2002 Ikatan Notaris Indonesia tahun.

[7] M. Hariwijaya 2007 Metodologi Dan Teknik Penulisan Skripsi Tesis Dan Disertasi Azzagrafika Yokyakarta. 